UDC 94(73)"1984":327

Submitted: 23.05 .2019

LBC 63.3(7Coe)63-6

Accepted: 09.03.2020

\title{
ORGANIZING THE MECHANISM OF CONDUCTING THE "SECRET WAR" OF THE USA AGAINST THE SANDINISTA REGIME OF 1984
}

\author{
Democrit M. Zamanapulov \\ Kuban State University, Krasnodar, Russian Federation
}

\begin{abstract}
Introduction. In Russian historiography, the issue of the reasons for the beginning of the U.S. special operations in Nicaragua is a complex problem that requires careful development due to its importance as one of the elements of the confrontation during the Cold War. The scientific relevance of this issue is determined by the insufficient degree of its study. The socio-political relevance is related to the current military-political situation in the world in general and the actions of the United States in particular, which, as part of ensuring their national security, use special operations to achieve certain goals and objectives. An example of this is the U.S.-led special operation to destroy Osama bin Laden, during which the sovereignty of Pakistan was violated. Another example of U.S. special operations at the present stage is Washington's support of the "proxy" forces loyal to it in Syria. Special operations conducted by the United States in Nicaragua during the first half of the 80 s were in many ways the main tool for achieving U.S. state interests in this country. In this regard, it seems that a detailed consideration of the first attempt in the history of the United States to conduct a global special operation, which began with the program of supporting the anti-Communist forces "Contras" in Nicaragua, which was later funded by the illegal supply of American weapons to Iran, would be useful for the domestic scientific doctrine. Methods and materials. In the course of the research, the historical-comparative method, the method of analysis and synthesis, as well as the system approach are applied. The study uses: 1) a set of unpublished materials on the special activities of the United States in Nicaragua, declassified in connection with the "Iran-Contra" scandal, and contained on the electronic website of the National Security Archive at the George Washington University; 2) published sources related to the Cold War; 3) scientific literature on the problems of U.S. special operations during the cold war; 4) memoir literature. Analysis. This article analyzes the reasons that influenced the decision of the U.S. political leadership to authorize special operations in Nicaragua based on the documents and materials studied in the Iran-Contra Affair. Results. The scientific development of the problems of the U.S. special policy in Nicaragua was observed back in the 80s in the USSR. However, it was conducted in hot pursuit, it was biased, considered a complex set of processes taking place in Central America from the perspective of the Marxist-Leninist doctrine, and did not take into account the American position, which made the scientific assessment of these events less complete and justified. New studies of this period take this factor into account, are based on new methods and previously unknown to the scientific community documents and materials that were declassified after the end of the Cold War. Results. In the course of the study, an attempt was made to highlight the mechanism for the development and implementation of U.S. special operations in Nicaragua. The author concludes that the use of the National Security Council personnel for special operations was conditioned by the need to avoid legislative restrictions of the U.S. Congress when implementing U.S. foreign policy in Nicaragua.
\end{abstract}

Key words: CIA, Central America, special operations, Boland amendments, secret war, "Contras".

Citation. Zamanapulov D.M. Organizing the Mechanism of Conducting the "Secret War" of the USAAgainst the Sandinista Regime of 1984. Vestnik Volgogradskogo gosudarstvennogo universiteta. Seriya 4. Istoriya. Regionovedenie. Mezhdunarodnye otnosheniya [Science Journal of Volgograd State University. History. Area Studies. International Relations], 2020, vol. 25, no. 3, pp. 77-89. (in Russian). DOI: https://doi.org/10.15688/jvolsu4.2020.3.7

\section{ОРГАНИЗАЦИЯ МЕХАНИЗМА ВЕДЕНИЯ «ТАЙНОЙ ВОЙНЫ» США ПРОТИВ РЕЖИМА САНДИНИСТОВ 1984 ГОДА}

\author{
Демокрит Малхазович Заманапулов \\ Кубанский государственный университет, г. Краснодар, Российская Федерация
}


Аннотация. Введение. Изучение первой в истории США попытки проведения глобальной специальной операции в первой половине 1980-х гг. в Никарагуа, начавшейся с программы поддержки антикоммунистических сил «контрас», которая в дальнейшем финансировалась за счет незаконных поставок американского оружия в Иран, представляется актуальной в связи со сложной современной военно-политической ситуацией в мире в целом и действиями США в частности. Методы и материалы. В ходе исследования применялись историко-сравнительный метод, метод анализа и синтеза, а также системный подход. В качестве материала использован содержащийся на сайтах Архива национальной безопасности при университете Дж. Вашингтона, а также Университета Брауна комплекс неопубликованных документов, посвященных специальной деятельности США в Никарагуа, рассекреченных в связи со скандалом «Иран-контрас», и опубликованные воспоминания американского сенатора П. Лихи. Анализ. Рассмотрены причины, повлиявшие на решение политического руководства США санкционировать проведение специальных операций в Никарагуа. Предпринята попытка освещения механизма разработки и реализации специальных операций США в Никарагуа. Результаты. Сделан вывод, что использование персонала Совета национальной безопасности для специальных операций обусловливалось необходимостью избежать законодательные ограничения Конгресса США при реализации внешней политики США в Никарагуа.

Ключевые слова: ЦРУ, Центральная Америка, специальные операции, поправки Боланда, секретная война, «контрас».

Цитирование. Заманапулов Д. М. Организация механизма ведения «тайной войны» США против режима сандинистов 1984 года // Вестник Волгоградского государственного университета. Серия 4, История. Регионоведение. Международные отношения. - 2020. - Т. 25, № 3. - С. 77-89. - DOI: https://doi.org/10.15688/ jvolsu4.2020.3.7

Введение. Начало 80-х гг. ХХ в., сопровождалось резкими сдвигами политических процессов, произошедших в результате Сандинистской революции в Никарагуа. Революционная борьба с режимом клана Анастасио Сомосы, которую возглавила военно-политическая организация «Сандинистский фронт национального освобождения» (СФНО) продлилась с 1962 по 1979 год. Ее главным отличием стала крайняя жестокость. По разным данным в результате противоборства между сторонами конфликта погибло около 50 тыс. никарагуанцев, 600 тыс. человек остались без крова, а экономика страны была отброшена на десятилетия назад [20, с. 54].

После победы революции новое коалиционное правительство Никарагуа объявило о своей ориентации на социалистический лагерь, приступило к налаживанию дипломатических отношений с СССР и Кубой. В частности, при активной поддержке последней были созданы Сандинистская народная армия, органы государственной безопасности и полиция. Экономическая политика сандинистов включала проведение аграрной реформы и обширную программу национализации, в результате которой имущество клана А. Сомосы перешло в собственность государства. Национализации и государственному контролю также подверглись частные банки и иностранные активы, находящиеся на территории Никарагуа.

Нужно сказать, что на первоначальном этапе сандинистам удалось добиться некоторых успехов в деле общегосударственного строительства, однако активное противодействие со стороны США стало постоянным фактором замедления никарагуанских реформ и угрозой режиму сандинистов в целом. К 1980 г. в связи с этой трудностью из коалиционного правительства сандинистов вышли умеренные фракции, не поддерживающие слишком активное проведение в жизнь кубинской модели развития страны. Силовые структуры Никарагуа контролировались братьями Даниелем и Умберто Ортега, которые опирались на политическую поддержку Кубы и СССР и обладали популярностью среди беднейших слоев никарагуанского общества. Этот факт позволял им управлять ходом развития страны. В 1980 г. в результате выборов президентом страны стал Д. Ортега, а его брат возглавил министерство обороны.

Столкнувшись с перспективой «второй Кубы» (только уже на материке, который Вашингтон считал своим «задним двором»), правительство США почти моментально приняло комплекс экономических, военных и дипломатических мероприятий, направленных на свертывание никарагуанских революционных 
процессов. В Вашингтоне рассматривались сценарии полномасштабного вторжения в Никарагуа с использованием всех видов вооруженных сил [16, p. 4]. Однако открытые действия армии США затруднялись рядом факторов. Прежде всего широкое международное признание режима сандинистов поставило Вашингтон перед большим риском оказаться в глазах мирового сообщества в роли агрессора. Кроме того, пропагандируемый администрацией Джимми Картера тренд неукоснительного соблюдения законности и прав человека не оставлял возможности администрации для политического маневра. ЦРУ, ослабленное после расследований комиссии Черча [2, с. 284], не смогло оказать помощи А. Сомосе в удержании власти из-за недостаточного финансирования его режима. И, наконец, комиссии Конгресса США по разведке осуществляли эффективный надзор за деятельностью специальных служб, что не позволяло оперативно решать вызовы, которые ставила Сандинистская революция.

Методы и материалы. Историко-сравнительный метод позволил анализировать процессные явления не изолированно друг от друга, но в тесной взаимосвязи и взаимовлиянии. Так, большое значение для настоящей статьи имели воспоминания американского сенатора Патрика Лихи, приведенные в работе журналиста Боба Вудворта «Признание шефа разведки». Основываясь на данных, полученных во время поездки в страны Центральной Америки, сенатор сообщил ценную информацию о механизме специальных операций движения «контрас» в Никарагуа, системе их обеспечения и поддержки со стороны американских специальных служб. Данные, отраженные в воспоминаниях П. Лихи, подтверждаются рассекреченными в ходе расследования скандала «Иранконтрас» официальными документами, которые также были использованы в настоящей статье.

Метод анализа и синтеза позволил добиться глубины и полноты исследования, подтвердить достоверность полученной информации. Системный подход послужил для теоретического осмысления и реконструирования объектов и систем как некой совокупности связанных между собой элементов, имеющих ресурсы, цель, связь с внешней средой и обратную связь.
Основной источниковой базы являются рассекреченные документы Белого дома, Совета по национальной безопасности, ЦРУ, Государственного департамента США, посвященные скандалу «Иран-контрас», извлеченные из собраний электронного Архива национальной безопасности при университете Дж. Вашингтона и коллекции документов университета Брауна. Указанные ресурсы содержат также рассекреченные документы международного отдела ЦК КПСС и МИД СССР, отражающие никарагуанскую проблематику периода 1980-х годов.

Анализ. Активная фаза никарагуанского кризиса началась в период правления администрации Дж. Картера. Эту эпоху в истории внешней политики США можно охарактеризовать как период соблюдения законности и прав человека как абсолютной ценности. Во многом данная политика стала ответом на президентство Ричарда Никсона, во время правления которого Вашингтон в глазах международного сообщества рассматривался как агрессор и спонсор государственных переворотов, позволяющих ликвидировать неугодных политических лидеров, по всему миру. Престиж США как цитадели демократии и законности был значительно подорван. Восстановление прежних ценностей и идеалов стало важной повесткой в политике, проводимой Дж. Картером. В связи с этим деятельность разведывательных органов США жестко регламентировалась законодательными актами, которые не позволяли проводить крупные операции за рубежом без уведомления комитета конгресса по разведке и вооруженным силам. Вместе с тем бюджет ЦРУ значительно сократился, что в свою очередь привело к снижению численности агентурной сети в Никарагуа.

Основная стратегия администрации Дж. Картера в борьбе с Сандинистской революцией - применение экономических санкций - была неэффективной, что могло стать следствием активной поддержки, оказываемой сандинистам Кубой и СССР. Нужно отметить, что фактор объема этой помощи требует научной разработки. Победа Сандинистской революции лишила США главного союзника в Центральной Америке в лице диктатора клана А. Сомосы. 


\section{ВОЕННЫЕ ОПЕРАЦИИ ХХ ВЕКА}

Правительство сандинистов в свою очередь в целях обеспечения собственной безопасности при активной помощи кубинских военных специалистов начало поставки вооружений в пограничные страны, в частности, в Сальвадор, где шла гражданская война, и Гватемалу. Тезис о поддержке сандинистами партизанских движений в соседних с Никарагуа странах подтверждается рассекреченными стенографическими материалами заседания политбюро ЦК КПСС от 6 мая 1982 г., на котором обсуждались итоги переговоров с государственными деятелями республики Никарагуа. В процессе дискуссии генеральный секретарь ЦК КПСС Л.И. Брежнев сообщил членам политбюро о том, что в ходе бесед лидеры сандинистов признали факт поставки оружия в соседние страны. В частности, он отметил: «Они также подчеркивали политические и дипломатические шаги, предпринятые руководством Никарагуа в последнее время. При этом, однако, говорили и о том, что продолжают поставки оружия партизанам Сальвадора и Гватемалы. Они даже похвастали, что делают это так ловко, что противник никак не может обнаружить пути, по которым доставляется оружие» [8]. Таким образом, перед Вашингтоном возникала перспектива падения лояльных правительств в Центральной Америке по принципу «домино». В этих условиях к власти в США пришла администрация Рональда Рейгана.

Примечательно, что свои антисандинистские настроения Р. Рейган обозначил еще будучи кандидатом на пост президента. В частности, в его предвыборной программе значилось: «Мы осуждаем захват власти в Никарагуа сандинистами-марксистами и попытки дестабилизировать Сальвадор, Гватемалу и Гондурас <...> Мы выступаем против программы помощи Дж. Картера правительству Никарагуа. Однако мы поддержим усилия народа Никарагуа по созданию свободного и независимого правительства < ..> Мы вернемся к фундаментальному принципу - будем относиться к другу как к другу, а к самопровозглашенному врагу - как к врагу» [4, с. 62].

Нужно отметить, что политика содействия новым президентом антисандинистским силам в 1984 г. нашла свое логическое завершение в так называемой доктрине Рейгана, суть которой заключалась в поддержке антикоммунистических сил по всему миру. Огромное влияние на доктрину Рейгана оказала концепция неореализма, представляющая международные отношения через призму вечного конфликта и перераспределения сил между государствами. Данная концепция справедливо считается основным принципом стратегии национальной безопасности администрации Р. Рейгана.

В соответствии с новой стратегией в январе 1981 г. был принят ряд мер, направленных на военное, дипломатическое и экономическое давление на правительство сандинистов.

Военная составляющая выразилась в проведении военно-морских учений ВМС США и ВМС Гондураса под кодовым названием «Авентура Осеаника-81», которые проходили вблизи берегов Никарагуа. Экономическое давление было организовано посредством блокировки непотраченной Никарагуа суммы в размере 15 млн долл., предоставленной администрацией Дж. Картера для оказания помощи в восстановлении никарагуанской экономики. Следующим шагом стало аннулирование кредита в размере 10 млн долл., который был выдан этой стране для покупки пшеницы. Далее американцами был заморожен кредит в размере 11,4 млн долл., ранее выделенный для проведения модернизации сельского хозяйства, систем образования и здравоохранения Никарагуа. Дипломатического давление США проявилось в ходе визита в страну заместителя госсекретаря США Томаса Эндерса.

Рассекреченные документы МИД СССР дают некоторое представление о поездке Т. Эндерса в Никарагуа. Из информации, переданной послу СССР в Никарагуа Герману Евлампиевичу Шляпникову членом сандинистского руководства Хайме Роман Уилоком, следует, что основная цель приезда заместителя госсекретаря США в страну заключалась в том «чтобы путем давления и угроз заставить их (сандинистов. - Д. 3.) отказаться от поддержки борьбы сальвадорских патриотов и не допустить укрепления оборонного потенциала страны» [1]. В донесении в Москву Г.Е. Шляпников пишет: «Т. Эндерс обвинил никарагуанские власти в транспортировке вооружения, боеприпасов и амуниции 
сальвадорским патриотам через никарагуанскую территорию, а также в переброске в Сальвадор партизан, прошедших подготовку в других странах, утверждая, что органы американской разведки располагают неопровержимыми данными на этот счет. Заявляя, что в Сальвадоре США не допустят военной победы левых сил, он подчеркивал опасность эскалации этого конфликта и его распространения на другие центрально-американские страны и утверждал, что добрые отношения между США и Никарагуа возможны только при прекращении сандинистами военной поддержки повстанцев в Сальвадоре» [1]. Т. Эндерс пытался доказать, что прекращение экономической помощи США Никарагуа было вызвано поставками никарагуанцами оружия в Сальвадор. Он утверждал, что если военная помощь Сальвадору полностью прекратится, то в Вашингтоне могут вновь рассмотреть вопрос о предоставленной ранее и иной гуманитарной помощи. Заместитель госсекретаря выразил готовность подписать двустороннее соглашение о принципах невмешательства во внутренние дела других стран, при условии что никарагуанцы согласятся с требованиями США о прекращении помощи патриотам Сальвадора. Это предложение было оставлено без ответа. Т. Эндерс отметил, что в США и соседних странах вызывает настороженную реакцию неоправданный, по их мнению, рост вооруженных сил Никарагуа. Он подчеркнул, что никарагуанская армия оснащается более современным вооружением, чем армии других центрально-американских государств, добавив, что присутствие в стране многочисленных кубинских военных советников еще более осложняет дело. Это, по мнению Т. Эндерса, вызывает страх у его соседей и нагнетает обстановку в Центральной Америке. Данная ситуация может перерасти в региональный конфликт, куда окажутся втянутыми и США. Говоря о внутриполитической линии сандинистского руководства, американский представитель отметил нарастание тенденции на отход от плюрализма в политике и смещение к политической системе унитарного типа. Со своей стороны, никарагуанские руководители решительно отвергли обвинения в причастности к транспортировке оружия для сальвадорских повстанцев через свою терри- торию. В отношении вопроса о вооружении Никарагуа сандинистские лидеры прямо утверждали, что опасаются американского вмешательства. Они обратили внимание Т. Эндерса на существование на территории США лагерей по подготовке бывших сомосовских гвардейцев для вторжения в Никарагуа, создание сил быстрого развертывания в зоне Центральной Америки и Карибского бассейна. Т. Эндерсу указывалось, что курс США на дестабилизацию обстановки затрагивает не только Никарагуа, но и весь регион. Военные советники США находятся и в Сальвадоре, и в Гондурасе. В Сальвадоре США поддерживают самые консервативные круги, те силы, которые препятствуют политическому урегулированию. Все это вынуждает никарагуанское руководство принимать необходимые меры самообороны.

Анализ дальнейших событий приводит к выводу, что комплекс экономических санкций и дипломатического давления не позволил США добиться прекращения предоставления сандинистами военной помощи партизанским движениям в соседних странах. Влияние советского и кубинского факторов на развитие революционных процессов в Центральной Америке могло привести к катастрофическим последствиям для США.

Некоторое представление о мощи сандинистской армии дает документ, отражающий динамику военных поставок стран советского блока в Никарагуа, которые были подготовлены ЦРУ. В период с июля 1979 г. по декабрь 1989 г. численность вооруженных сил сандинистов, учитывая резервы и силы безопасности, составляла 120000 солдат. Это не намного уступало совокупной численности армий четырех государств региона (Сальвадора, Гватемалы, Гандураса и Коста-Рики), вооруженные силы которых насчитывали 131840 солдат.

На вооружении сандинистской армии находилось 152 танка, 237 видов военно-транспортных средств, 549 зенитно-ракетных установок, 772 противовоздушные зенитные ракеты, 370 противотанковых ракет, 985 артиллерийских систем, 66 вертолетов (12 - Ми-25, 45 Ми-8), 20 самолетов, 6000 грузовиков, 8 патрульных лодок, 8 тральщиков, 40 радарных систем, 4 станции средств радиоперехвата. Пе- 
хота имела 252000 винтовок, 4300 пулеметов, 3850 гранатометов. ВВС Никарагуа базировались на аэродромах Пунта-Хуерте, Сандино, Монтелимар, Пуэрто-Кабезас, Ла-Росита, Эстель и имели в наличии самолеты Миг-21 и Миг-23, поставленные кубинцами. В Никарагуа на постоянной основе находилось от 1 000-1 500 кубинских и 50-75 советских военных советников, около 200 военных специалистов из стран восточного блока, включая представителей Северной Кореи. Поставки военного снаряжения и оборудования в никарагуанские порты Коринто, Эль-Блуфф, Рама начались в 1980 г. и к 1988 г. составили 140000 т на общую сумму в 2 млрд долл. [7].

Вышеперечисленные угрозы и невозможность открытой военной интервенции в Никарагуа сильно повлияли на решение Р. Рейгана перейти к специальным средствам для борьбы с режимом сандинистов в Никарагуа. Для выполнения этой задачи было решено задействовать оперативные возможности ЦРУ.

Новый директор агентства Уильям Кейси, имевший опыт диверсионной работы в годы Второй мировой войны, предпочитал более агрессивный метод ведения разведывательной работы, чем предыдущий руководитель агентства адмирал Стендфорд Тернер. При разработке плана войны против сандинистов У. Кейси исходил из возможности «перехвата» уже реализуемых программ проведения секретных операций у третьих стран. Нужно сказать, что ЦРУ имело опыт подобного «перехвата» специальных операции в Чаде у французских специальных служб. Тогда ЦРУ заменило французскую разведку в обеспечении финансирования и обучении группировок, ведущих борьбу против влияния полковника Муаммара Каддафи в Чад, где шла гражданская война. В вопросе проведения специальных операций против сандинистов было решено прибегнуть к помощи Аргентины.

Резидентура ЦРУ в Буэнос-Айресе тесно сотрудничала с верхушкой армии страны. Аргентинские военные из 601-го разведывательного батальона министерства обороны совместно с сотрудниками «Секретариата разведки Аргентины» в рамках операции «Чарли» поддерживали и обучали антисандинистские силы на военных базах в Лепатерике на территории Гондураса [11]. Цель аргентинцев заключалась в пресечении поддержки сандинистами группировок «монтенерос», которые выступали против военной хунты в Аргентине. Имелась и другая альтернатива - Чили. Однако в подобном случае США рисковали вступить в отношения с крайне непопулярным во всем мире режимом генерала Аугусто Пиночета. Опираясь на имеющиеся в научном обороте документы, можно утверждать, что программа по проведению специальных операций в Никарагуа при помощи аргентинских военных была санкционирована Р. Рейганом 1 декабря 1981 года [10].

Основным инструментом противостояния сандинистам являлись силы «конрас» (от лат. contra - «против»), которые были объединены в военно-политическую организацию «Никарагуанские демократические силы». Стратегия «контрас», применявшаяся в Гондурасе, заключалась в действиях небольших групп, входящих на территорию Никарагуа, как правило, глубокой ночью. Далее они занимали удобные позиции, устраивали засады на отряды сандинистских войск, после чего организованно отходили обратно на территорию Гондураса. Основными целями для нападения являлись пути сообщения, линии и узлы связи, промышленные предприятия, склады, административные и правительственные учреждения, казармы и военная инфраструктура. Политически «контрас» включало представителей почти всех слоев никарагуанского общества, недовольных проводимой сандинистами политикой.

Подразделения движения в основном состояли из бывших бойцов национальной гвардии А. Сомосы и бедных крестьян. С 1981 г. существенным фактором пополнения сил «контрас» стало индейское население Москитии, проживавшее на атлантическом побережье Никарагуа. Сильная позиция церкви, а также политика сандинистского правительства, направленная на более тесную интеграцию региона в дело социалистического строительства (что в свою очередь меняло вековые устои жизни индейского населения), не находила понимания со стороны последних. В регион были направлены кубинские учителя и врачи, прибытие которых расценивалось местным населением как первый этап в политике правительства по изъятию у них земли и бо- 
лее интенсивному заселению региона. Это привело к демонстрациям и протестам, переросшим в вооруженные столкновения с сандинистской милицией.

Нужно сказать, что ЦРУ уже располагало опытом в деле организации военизированных подразделений из представителей национальных меньшинств. В частности, американская разведка действовала так в Лаосе, где из народности мяо были созданы силы, впоследствии воевавшие против коммунистов. Эта практика применялась и в Никарагуа, где индейское население Москитии активно вербовалось в отряды «контрас». Таким образом, ЦРУ при помощи обещаний признания независимости Москитии после победы над сандинистами решило использовать индейцев мискито, для открытия нового фронта против сандинистов в джунглях Москитии.

Примечательно, что первое крупное наступление против сандинистов было организовано ЦРУ силами индейцев. Операция получила кодовое название «Кровавое рождество», так как проводилась в конце 1981 года. Ее целью был захват стратегически важного порта Пуэрто-Кабесаса, после чего планировалось объявление временного правительства и обращение к правительству Соединенных Штатов с просьбой о военной помощи.

В ходе реализации указанной операции силами «контрас», куда входили индейцы москито, была организована засада, в которую попал патруль сандинистской армии из 12 человек. В процессе боестолкновения, произошедшего 14 декабря 1981 г., его полностью уничтожили. Следующее столкновение произошло 18 декабря. Его результатом стало убийство еще 3 солдат сандинистской армии. 21 декабря «контрас» организовали нападение на военный вертолет и уничтожили еще 8 солдат правительственной армии. Таким образом, в результате операции «Красное рождество», спланированной ЦРУ, было убито 45 солдат и офицеров сандинистской народной армии. Данная операция стала первой страницей в секретной войне США против сандинистов $[17$, с. 526$]$.

Нужно сказать, что ЦРУ предпринимало попытки привлечь к движению «контрас» разочаровавшегося в политике сандинистов видного деятеля Эдена Пастору, который к этому времени организовал оппозиционный действующему правительству «Сандинистский революционный фронт» (FRS). Однако Э. Пастора отверг поступавшие от американской разведки предложения сотрудничества с бывшими самосистами из движения «контрас». Он справедливо полагал, что подобный шаг отрицательно сказался бы на его политической карьере. По этой причине движение Э. Пасторы действовало автономно от деятельности «контрас», в связи с чем, не имея достаточного финансирования, политик был вынужден прекратить борьбу с сандинистским правительством в 1986 году.

К началу 1982 г. «контрас» представляли собой хорошо вооруженную, имеющую четкую военную иерархию и политическое руководство силу. Численность «контрас» к ноябрю 1982 г. возросла до 10 тыс. бойцов [5]. Посол США в Никарагуа Эдвард Квейнтон вспоминал, что «секретная война началась 15 марта 1982 г., когда ЦРУ, используя никарагуанских агентов, взорвало мосты, соединявшие Никарагуа с Гондурасом» [3, с. 380].

Некоторое представление о механизме специальных операций ЦРУ в Никарагуа могут дать воспоминания американского сенатора-демократа П. Лихи. Он побывал в Центральной Америке в 1982 году. Целью его поездки было намерение лично побеседовать с резидентами ЦРУ в четырех странах региона и узнать у них подробности секретных операций против сандинистов.

П. Лихи подготовил доклад, содержащий записи всего увиденного. Его выводы были недвусмысленными: секретные операции против сандинистов почти по всем пунктам превышали первоначальные цели по пресечению поставок никарагуанского оружия мятежникам в Сальвадоре и других странах региона. Численность подразделений «контрас» составляла 5500 человек, что было значительно выше дозволенного лимита. Американские военные и специалисты ЦРУ организовали полномасштабную войну, требующую миллионы долларов. Все страны региона - Гватемала, Коста-Рика, Сальвадор, Гондурас и Панама состояли в неофициальном военном союзе против Никарагуа. Подобное положение дел не устраивало сенаторов-демократов в профильных комитетах конгресса США. По сути, 
администрация Р. Рейгана тратила миллионы долларов на ведение несанкционированной со стороны конгресса войны с сандинистами в Никарагуа. В этой связи конгресс был полон решимости помешать Р. Рейгану проводить указанную политику в Центральной Америке.

Данные, отраженные в докладе П. Лихи, подтверждаются официальными документами, рассекреченными в ходе расследования скандала «Иран-контрас» (см.: [6; 9; 10]). Ключевым в этом отношении документом является протокол заседания группы планирования национальной безопасности по вопросу внешней политики в отношении Центральной Америки от 25 июня 1984 году [18]. На встрече высших должностных лиц администрации Р. Рейгана обсуждался вопрос о поддержании военных акций «контрас» в Никарагуа перед лицом растущей оппозиции со стороны конгресса. Дискуссия была сосредоточена на том, чтобы просить третьи страны финансировать и поддерживать эти усилия, обходя ограничения конгресса, направленные на свертывание военизированных операций ЦРУ. Согласно указанному документу государственный секретарь Джордж Шульц предупредил Р. Рейгана: «Если мы попытаемся получить деньги из третьих стран, это будет основанием для импичмента» [18]. Вице-президент Джордж Буш не согласился с этой оценкой и в свою очередь заметил: «Как можно возражать против того, чтобы США попросили третьи стороны оказывать помощь антисандинистам? Единственная проблема, которая может возникнуть, это если Соединенные Штаты пообещают дать этим странам что-то взамен, что могло выглядеть как своего рода обмен» [18]. Позже он участвовал в организации сделки по принципу quid pro quo (услуга за услугу) с Гондурасом, в которой США действительно оказывали значительную скрытую и явную помощь гондурасским военным в обмен на поддержку Гондурасом военных усилий движения «контрас». Примечательно, что Р. Рейган закончил встречу язвительным предупреждением никому не говорить об этом вопросе: «Если такая история выйдет наружу, мы все будем висеть перед Белым домом, пока не выясним, кто это сделал» [18]. Именно этот подход в дальнейшем отражал решимость администрации отрицать всю информацию об этой программе после того, как в ноябре 1986 г. разразился скандал «Иран-контрас».

Участие других стран в борьбе с сандинистами подтверждает и распечатка электронного сообщения, поступившего от Оливера Норта советнику президента США по национальной безопасности Джону Пойндекстеру 23 августа 1986 года. Несмотря на тот факт, что основная тема письма касалась Ирана, речь в нем шла о встрече О. Норта с представителем панамского диктатора Мануэля Норьеги. На ней обсуждались вопросы американо-панамского взаимодействия в борьбе с сандинистами. О. Норт писал Дж. Пойндекстеру: «Вы помните, что за эти годы у нас с Мануэлем Норьегой в Панаме сложились довольно хорошие отношения. Если американские чиновники помогут очистить его имидж и снимут запрет на продажу оружия панамской армии, Норьега позаботится о сандинистском руководстве». По всей видимости, О. Норт имел в виду программу по физической ликвидации лидеров сандинистского движения. Далее он сообщает, что М. Норьега может помочь в вопросе организации диверсий и актов саботажа против сандинистов, и предлагает заплатить диктатору миллион долларов из средств, собранных от продажи американского оружия Ирану, за помощь панамского лидера в уничтожении никарагуанских экономических объектов [13].

Еще одним доказательством сотрудничества (на этот раз военных Гондураса) в борьбе с сандинистами служит сообщение О. Норта Дж. Пойндекстеру от 17 сентября 1986 года. В указанном сообщении речь шла о генерале гондурасской армии Хосе Буэсо Роса, активно помогавшем ЦРУ в организации специальных операций против сандинистов. В 1984 г. Х.Б. Роса и группа его сообщников организовали заговор с целью убийства президента Гондураса Роберто Суазо Кордовы, который должен был финансироваться за счет поставки в США кокаина на сумму 40 млн долл., перехваченного ФБР во Флориде. Рассекреченные сообщения электронной почты, подобные этому, указывают на роль О. Норта в попытке добиться снисхождения для Х.Б. Роса из-за его прошлых заслуг перед движением «контрас» [12]. 
Таким образом, мы видим, что воспоминания П. Лихи имели под собой фактическую основу и подтверждают существенное расширение программы «контрас», вылившееся в полномасштабную войну с участием ряда стран Центральной Америки.

В ноябре 1982 г. в журнале «Ньюсуик» вышла статья под названием «Секретная война Америки, цель - Никарагуа» [19]. В ней утверждалось, что первоначальная линия на пресечение поставок оружия сальвадорским партизанам превратилась в крупномасштабную войну с целью свержения сандинистского правительства. Становилось очевидным, что, проходя логическую цепочку Белый дом - Ленгли - резидентура ЦРУ в Центральной Америке - силы «контрас», операция по достижению умеренных целей пресечения поставок никарагуанского оружия в Сальвадор существенно трансформировалась. Она превращалась в полномасштабные военные действия, нацеленные на свержение сандинистов. Подобное положение вещей не устраивало конгресс, не желающий втягивать США в новую непопулярную войну в джунглях. 8 декабря 1982 г. сенатор Эдвард Боланд зачитал в палате представителей разработанный им проект, в соответствии с которым запрещалось использовать государственные фонды для свержения сандинистского правительства. Проект был полностью поддержан другими сенаторами и принят в качестве поправки к закону о разведывательных полномочиях [15].

Ход дальнейших событий позволяет прийти к выводу, что указанные ограничительные меры со стороны конгресса США не повлияли на решимость администрации Р. Рейгана свергнуть сандинистское правительство в Никарагуа. С 1984 г. ЦРУ приступило к осуществлению секретной программы по минированию никарагуанских портов с целью пресечения поставок нефти для подрыва экономики страны. В результате серии взрывов в территориальных водах Никарагуа были повреждены 11 судов различных стран, в том числе и СССР. Этот факт вызвал международный скандал, что привело к принятию еще одной ограничительной поправки, разработанной также сенатором Э. Боландом.

Ко времени принятия поправки Боланда в 1983 г. и позднее, в 1984 г., администрация
Р. Рейгана взяла на себя «жесткое» обязательство поддерживать «контрас» любой ценой. Эта политика не могла быть осуществлена без игнорирования позиции конгресса. После принятия поправок Боланда оказывать помощь «контрас» стало политически неосуществимо. Единственным способом сделать это было проведение секретных операций, неподконтрольных надзорным комитетам конгресса, что являлось прямым нарушением американского законодательства.

Поправки Боланда запретили использование любых средств и возможностей, доступных ЦРУ, Министерству обороны США или «любому другому агентству или организации, участвующей в разведывательной деятельности» для свержения режима сандинистов в Никарагуа [20]. Этот запрет оставлял две возможности, используя которые администрация могла обойти ограничительные барьеры. Одна из них заключалась в том, чтобы к указанной работе привлечь сотрудников Совета национальной безопасности (далее СНБ) вместо агентов ЦРУ, не имеющее право участвовать в реализации спецопераций. Директива президента Р. Рейгана № 12333 от 4 декабря 1981 г., регулирующая состав разведывательного сообщества США, не упоминала СНБ в качестве организации, занимающейся разведывательной деятельностью [14]. Таким образом, полагая, что сотрудники СНБ по закону не относятся к спецслужбам, было решено привлечь именно их. Вместе с тем в финансовом плане законодательные ограничения вынуждали администрацию использовать средства «частных» лиц из третьих стран, поскольку участие американских официальных лиц в этой деятельности было запрещено. Описанные методы были связаны между собой, так как в дальнейшем советник по национальной безопасности, его сотрудники и другие высокопоставленные лица были прямо или косвенно вовлечены в процесс привлечения средств из третьих стран для «контрас». Таким образом, у администрации Р. Рейгана возникла проблема с финансированием этого движения. Помощь в данном вопросе поступила из неожиданного источника - Ирана.

К этому времени победа Исламской революции в Иране лишала США своего главного союзника в другой важнейшей с геопо- 
литической и экономической позиций точке планеты. Падение шахского режима Пехлави существенно трансформировало внутреннюю и внешнюю политику страны. Доминированию США в Иране пришел конец, дипломатические отношения между странами были прерваны. Изменение ситуации на иранском направлении американской внешней политики произошло благодаря деятельности двух иностранных бизнесменов - саудовского миллиардера Аднана Хашогги и иранского торговца оружием Манучера Горбанифара. В ходе их встречи М. Горбанифар подчеркнул, что является представителем либерально настроенной группы в иранском высшем руководстве и имеет полномочия установить контакт с США, для того чтобы наладить закупку необходимого Ирану оружия. В обмен он был готов способствовать освобождению американских заложников в Ливане и вывести ирано-американские отношения из тупика. М. Горбанифар подчеркнул, что поставка американского оружия в армию Исламской республики Иран усилит политические возможности либералов в иранском руководстве и позволит им прийти к власти после смерти Аятоллы Хомейни. Эти предложения заинтересовали Вашингтон: Р. Рейган стремился освободить американских заложников и вывести ирано-американские отношения на новый уровень.

Дальнейшие контакты М. Горбанифара с американцами при посредничестве Израиля привели к серии секретных поставок американского оружия в Иран, что противоречило официальной политике США по оружейному эмбарго Ирана.

В результате сделок, осуществленных структурами О. Норта - на тот момент главного лица во всех важнейших внешнеполитических операциях США, - средства, поступившие от продажи оружия Ирану, было решено использовать для финансирования деятельности «контрас» в Никарагуа. Отметим, что иранские деньги позволили поставлять движению современное вооружение и тем самым решить проблему администрации Р. Рейгана в финансировании тайной войны с сандинистами вплоть до ноября 1986 г., когда скандал «Иран-контрас» положил конец этим операциям.
Результаты. На первоначальном этапе никарагуанского кризиса администрация Дж. Картера реагировала пассивно на вызовы, возникшие в результате Сандинистской революции. Основной стратегией, используемой Дж. Картером, было оказание экономического давления, что не являлось эффективным средством по борьбе с экспортом Сандинистской революции на соседние страны. Приход к власти Р. Рейгана ознаменовался принятием Белым домом новой стратегии по обеспечению национальной безопасности. Проводимая ЦРУ программа секретных операций игнорировала американское законодательство, что привело к принятию ограничительных поправок Боланда. Указанные поправки сделали невозможным участие министерства обороны или ЦРУ в деле поддержания «контрас». Именно по этой причине было решено прибегнуть к помощи сотрудников СНБ, которые по закону не относились к специальным службам. Данное обстоятельство позволило администрации продолжать операции в Никарагуа, избегая надзора и ограничений со стороны конгресса. Сотрудником СНБ, выбранным для этой цели, был подполковник морской пехоты О. Норт, который проходил стажировку в аппарате помощника президента по национальной безопасности.

Таким образом, к осени 1984 г. СНБ через О. Норта заняло место ЦРУ в деле поддержания антисандинистского движения «контрас». О. Норт в свою очередь при помощи ЦРУ создал миниатюрную версию разведывательной службы, занимающейся поставками оружия силам «контрас». Преимущество использование подобной службы заключалось в том, что в нее входили частные лица, которым не нужно было давать показания перед комитетами конгресса и получать платежи, отслеживаемые правительством США. Пока О. Норт был единственной точкой соприкосновения с правительством, созданная им при помощи ЦРУ система, или, как ее иногда называли, «Предприятие» (Enterprise), была менее уязвима для воздействия со стороны конгресса.

Вместе с тем принятие поправок Болланда существенно ограничило финансирование движения. Для администрации Р. Рейгана возникла потребность в привлечении альтерна- 
тивных средств обеспечения деятельности этого движения. На первоначальном этапе было решено использовать средства, полученные в результате благотворительных вечеров и поступлений от бизнесменов из других стран. Однако их было явно недостаточно для ведения полномасштабной войны с режимом сандинистов в Никарагуа. К этому времени были установлены секретные контакты с Ираном через Израиль. Поступившие от продажи оружия Тегерану средства были переведены для деятельности «контрас» в Никарагуа. Примечательным моментом в данных операциях стало то, что их выполнение курировали одни и те же люди из аппарата СНБ, и главную роль в этой деятельности играл О. Норт.

\section{СПИСОК ЛИТЕРАТУРЫ}

1. Ахтамзян, Н. И. Тайные операции США в Чили 1963-1973 по материалам Комиссии Черча / Н. И. Ахтамзян // Латиноамериканский исторический альманах. - 2015. - № 15. - С. 284-301.

2. Вейнер, Т. ЦРУ. Правдивая / Т. Вейнер. - М. : Центрполиграф, 2013. $-728 \mathrm{c}$.

3. Горнов, М. Ф. Никарагуа : возрожденная земля Сандино / М. Ф. Горнов, Н. Ю. Смирнова. М. : Политиздат, 1986. -156 с.

4. [Документ госдепартамента США, отражающий экономическую помощь, оказанную республике Никарагуа] // [Документы университета Брауна]. - Электрон. текстовые дан. - Режим доступа: https://www.brown.edu/Research/Understanding the Iran_Contra_Affair/documents/d-nic-1.pdf(дата обращения: 06.05.2019).

5. Дояр, П. Секретная война в Никарагуа / П. Дояр // Newsweek. - 1982. - 08 нояб.

6. Основное содержание бесед руководителей Никарагуа с заместителем госсекретаря США по межамериканским делам Томасом Эндерсом : аннотация // Документы российских программ Архива национальной безопасности. - Электрон. текстовые дан. - Режим доступа: https://nsarchive2. gwu.edu/rus/text_files/BrezhnevEpoch/1981.10.30\% 20Enders\%20Conversations\%20with\%20Nicaraguan\% 20Leadership.pdf (дата обращения: 06.05.2019).

7. Платошкин, Н. Н. Сандинистская революция в Никарагуа / Н. Н. Платошкин. - М. : Университет Дмитрия Можарского, 2015. - 781 с.

8. Стенограмма заседания Политбюро ЦК КПСС от 6 мая 1982 года «Об итогах переговоров с государственной делегацией республики Никарагуа» // Документы российских программ Архива национальной безопасности. - Электрон. тек- стовые дан. - Режим доступа: http://nsarchive2.gwu. edu//rus/text files/BrezhnevEpoch/1982.05.06.PDF (дата обращения: 06.05.2019).

9. Страны Центральной Америки : тенденции экономического и социально-политического развития : сб. ст. / отв. ред. В. В. Вольский. - М. : Наука, $1986 .-336 \mathrm{c}$.

10. Строгонова, Е. Д. Политика США в отношении левых режимов Латинской Америки / Е. Д. СТрогонова // Берегиня. 777. Сова: Общество. Политика. Экономика. - 2012. - № 4 (15). - С. 51-60.

11. Chomsky, N. What Uncle Sam Really Wants /N. Chomsky. - Brooklyn : Odonian Press, 1986.-111 p.

12. Document 06. White House, PROFS (e-mail) Message from Oliver North to John Poindexter, "Iran", August 23, 1986 // National Security Archive. Electronic text data. - Mode of access: https://nsarchive2. gwu.edu//dc.html?doc=4463973-Document-06-WhiteHouse-PROFS-e-mail-message (date of access: 06.05.2019).

13. Document 07. White House, PROFS (e-mail) message from Oliver North to John Poindexter, September 17, 1986 // National Security Archive. Electronic text data. - Mode of access: https:// nsarchive2. gwu. edu//dc.html? doc $=4463974$ Document-07-White-House-PROFS-e-mail-message (date of access: 06.05.2019).

14. Executive Order 12333 «United States Intelligence Activities. December 4, 1981» (As Amended by Executive Orders 13284 (2003), 13355 (2004) and 13470 (2008)) 12333) // Central Intelligence Agency. - Electronic text data. - Mode of access: https://www.cia.gov/about-cia/eo12333.html (date of access: 06.05.2019).

15. Finding Pursuant to Section 662 of the Foreign Assistance Act of 1961, As Amended, Concarning Operations Undertaken by the Central Intelligence Agency in Foreign Countries, Other Than Those Intented Solely for the Purpose of Intelligence Collection [=Директива Р. Рейгана о проведении спецопераций в Центральной Америке] // National Security Archive [= Документы Архива национальной безопасности]. - Электрон. текстовые дан. Режим доступа: https://www.brown.edu/Research/ Understanding the_Iran_Contra_Affair/documents/ d-all-45.pdf (date of access: 06.05.2019).

16. Kornbluh, P. Nicaragua, the Price of Intervention: Regan's Wars Against the Sandinistas / P. Kornbluh. - Washington : Institute for Policy Studies, 1987. $-287 \mathrm{p}$.

17. National Security Decision Directive № 37 (May 28, 1982) [= Директива совета по национальной безопасности США № 37 от 28 мая 1982 г.] // National Security Archive [= Документы Архива национальной безопасности]. - Electronic tex data. Mode of access: https://fas.org/irp/offdocs/nsdd/ nsdd-037.htm (date of access: 06.05.2019). 
18. National Security Planning Group Minutes June 25, 1984 // National Security Archive. - Electronic text data. - Mode of access: https://nsarchive2. gwu.edu//dc.html?doc=3224970-01-NSC-NationalSecurity-Planning-Group-Minutes (date of access: 06.05.2019).

19. Scope of CIAActivities Under the Nicaragua Finding [= Деятельность ЦРУ в Никарагуа] // [Документы университета Брауна]. - Electronic tex data. Mode of access: https://www.brown.edu/Research/ Understanding_the_Iran_Contra_Affair/documents/ d-all-19.pdf(date of access: 06.05.2019).

20. The Boland Amendment [= Поправки сенатора Э. Боланда, к закону об ассигнованиях на разведывательную деятельность] // [Документы университета Брауна]. - Electronoc text data. - Mode of access: https://www.brown.edu/Research/Understanding _ the_Iran_Contra_Affair/documents/d-nic-7.pdf(date of access: 06.05 .2019 ).

\section{REFERENCES}

1. Akhtamzyan N.I. Taynye operatsii SShA v Chili 1963-1973 po materialam Komissii Chercha [Secret Operations of the USA in Chile 1963-1973 Based on Materials of the Church Committee]. Latinoamerikanskiy istoricheskiy almanakh [Latin-American Historical Almanac], 2015, no. 15, pp. 284-301.

2. Veyner T. TsRU. Pravdivaya istoriya [CIA. True History]. Moscow, TsentrpoligrafPubl., 2013. 728 p.

3. Gornov M.F. Smirnova N.Yu. Nikaragua: vozrozhdennaya zemlya Sandino. [Nicaragua: The Revived Land of Sandino]. Moscow, Politizdat, 1986.156 p.

4. Dokument gosdepartamenta SShA, otrazhayushchiy ekonomicheskuyu pomoshch, okazannuyu respublike Nikaragua [Document of the U.S. State Department Reflecting the Economic Assistance Provided to the Republic of Nicaragua]. Dokumenty universiteta Brauna [Brown University Documents]. URL: https://www.brown.edu/Research/ Understanding the Iran_Contra_Affair/documents/ d-nic-1.pdf(accessed 6 May 2019).

5. Doyar P. Sekretnaya voyna v Nikaragua [Secret War in Nicaragua]. Newsweek, 1982, November 8.

6. Osnovnoe soderzhanie besed rukovoditeley Nikaragua s zamestitelem gossekretarya SShA po mezhamerikanskim delam Tomasom Endersom: annotatsiya [Main Content of the Conversations of the Nicaraguan Leadership with U.S. Under Secretary of State T. Enders. Abstract]. Dokumenty rossiyskikh programm Arkhiva natsionalnoy bezopasnosti [Documents of the Russian Programs of the National Security Archive]. URL: http://nsarchive2.gwu.edu// rus/text_files/BrezhnevEpoch/1981.10.30\%20Enders\%
20Conversations\%20with\%20Nicaraguan\%20Leadership.pdf. (accessed 6 May 2019).

7. Platoshkin N.N. Sandinistskaya revolyutsiya $v$ Nikaragua [Sandinista Revolution in Nicaragua]. Moscow, Universitet Dmitriya Mozharskogo, 2015.781 p.

8. Stenogramma zasedaniya Politbyuro TsK KPSS ot 6 maya 1982 goda «Ob itogakh peregovorov s gosudarstvennoy delegatsiey respubliki Nikaragua» [Transcript of the Meeting of the Central Committee of the CPSU of May 61982 "On the Results of Negotiations with the State Delegation of the Republic of Nicaragua"]. Dokumenty rossiyskikh programm Arkhiva natsionalnoy bezopasnosti [Documents of the Russian Programs of the National Security Archive]. URL: http://nsarchive2.gwu.edu//rus/ text_files/BrezhnevEpoch/1982.05.06.PDF (accessed 6 May 2019).

9. Volskiy V.V., ed. Strany Tsentralnoy Ameriki: tendentsii ekonomicheskogo i sotsialno-politicheskogo razvitiya: $s b$. st. [Central American Countries: Trends in Economic and Socio-Political Development. Collected Articles]. Moscow, Nauka Publ., 1986. 336 p.

10. Strogonova E.D. Politika SShA v otnoshenii levykh rezhimov Latinskoy Ameriki [U.S. Policy Towards the Left Regimes of Latin America]. Bereginya. 777. Sova: Obshchestvo. Politika. Ekonomika, 2012, no. 4 (15), pp. 51-60.

11. Chomsky N. What Uncle Sam Really Wants. Brooklyn, Odonian Press, 1986. 111 p.

12. Document 06. White House, PROFS (e-mail) Message from Oliver North to John Poindexter, "Iran", August 23, 1986. National Security Archive. URL: https://nsarchive2. gwu.edu//dc.html?doc=4463973Document-06-White-House-PROFS-e-mail-message (accessed 6 May 2019).

13. Document 07. White House, PROFS (e-mail) Message from Oliver North to John Poindexter, September 17, 1986. National Security Archive. URL: https://nsarchive2.gwu.edu//dc.html?doc=4463974Document-07-White-House-PROFS-e-mail-message (accessed 6 May 2019).

14. Executive Order 12333 "United States Intelligence Activities. December 4, 1981" (As Amended by Executive Orders 13284 (2003), 13355 (2004) and 13470 (2008)) 12333). Central Intelligence Agency. URL: https://www.cia.gov/about-cia/eo12333. html (accessed 6 May 2019).

15. Finding Pursuant to Section 662 of the Foreign Assistance Act of 1961, As Amended, Concerning Operations Undertaken by the Central Intelligence Agency in Foreign Countries, Other Than Those Intended Solely for the Purpose of Intelligence Collection. National Security Archive. URL: https:// www.brown.edu/Research/Understanding the Iran_Contra_Affair/documents/d-all-45.pdf(accessed 6 May 2019). 
Д.М. Заманапулов. Организация механизма ведения «тайной войны» США против режима сандинистов

16. Kornbluh P. Nicaragua, the Price of Intervention: Regans Wars Against the Sandinistas. Washington, Institute for Policy Studies, 1987.287 p.

17. National Security Decision Directive№37 (May 28, 1982). National Security Archive. URL: https://fas.org/ irp/offdocs/nsdd/nsdd-037.htm (accessed 6 May 2019).

18. National Security Planning Group Minutes June 25, 1984. National Security Archive. URL: https:/ /nsarchive2.gwu.edu//dc.html?doc=3224970-01-NSCNational-Security-Planning-Group-Minutes (accessed 6 May 2019).
19. Scope of CIAActivities Under the Nicaragua Finding. Dokumenty universiteta Brauna [Brown University Documents]. URL: https://www.brown. edu/Research/Understanding_the_Iran_Contra Affair/documents/d-all-19.pdf (accessed 6 May 2019).

20. The Boland Amendment. Dokumenty universiteta Brauna [Brown University Documents]. URL: https://www.brown.edu/Research/Understanding the_Iran_Contra_Affair/documents/d-nic-7.pdf (accessed 6 May 2019).

\section{Information About the Author}

Democrit M. Zamanapulov, Postgraduate Student, Department of General History and International Relations, Kuban State University, Stavropolskaya St., 149, 350040 Krasnodar, Russian Federation, dz750@mail.ru, https://orcid.org/0000-0003-3682-1241

\section{Информация об авторе}

Демокрит Малхазович Заманапулов, аспирант кафедры всеобщей истории и международных отношений, Кубанский государственный университет, ул. Ставропольская, 149, 350040 г. Краснодар, Российская Федерация, dz750@mail.ru, https://orcid.org/0000-0003-3682-1241 